\title{
Geological control of mineral deposits in Nepal
}

\author{
Ram Bahadur Sah and * Kabi Raj Paudyal \\ Central Department of Geology, Tribhuvan University, Kirtipur, Kathmandu, Nepal \\ *Corresponding author: paudyalkabi1976@gmail.com
}

\begin{abstract}
Systematic information and in-depth knowledge of geological controls, mode of occurrences, distribution patterns and mineral association are very essential for exploring the new deposits and development of mineral resources of the country in general. In present study, an attempt has been made to clarify the geological controls of economic and sub-economic mineral deposits of Nepal. Investigation has shown that mineral deposits in Nepal Himalaya are controlled by particular geological conditions and tectonics. Till the date, economic potential of 63 mineral commodities from Nepal have been established by Department of Mines and Geology. Several economic to sub economic deposits of the country are explored and some are under mining process. Analysis of geological controls of above mentioned economic and sub-economic mineral deposits shows that they are either syngenetically or epigenetically confined to particular stratigraphic and tectonic units. These deposits are related in time and space to certain events of crustal movement representing different metallogenic epochs.
\end{abstract}

Keywords: Mineral resources, Metallogeny, Geological controls, Nepal Himalaya

Paper Received: 15 Jan 2019

Paper Accepted: 30 Mar 2019

\section{INTRODUCTION}

Mineral resources play an important role in the development of a country. All countries want to be self-sufficient with respect to mineral resources as the mineral based industries play a vital role in country's economic development. Nepal is fortunate to have a good number of mineral deposits required for industrial development. At present only few mineral based industries are developed but there is big future ahead. Altogether economic potential for 63 mineral commodities have been found in Nepal (DMG, 2004; 2011). But the reserves of the explored economic minerals are limited and they are not replenishable once mined. This fact requires sticking to proper and full utilization of the available natural resources and scientific attempt should be made towards the finding of new deposits of mineral wealth. This is possible only with clear understanding of geological control of mineralization, their regional distribution pattern and local condition of their occurrences.

The geological processes that are responsible for concentration of these diffused elements/ scattered minerals into economic deposits are magmatic concentration, sublimation, contact metasomatism, hydrothermal processes, sedimentation, evaporation, residual and mechanical concentration, surficial oxidation and supergene enrichment and metamorphism.

Investigations have shown that regional distribution of mineral deposits are controlled by the geological evolution of the region, local and regional tectonics, magmatic activities etc. that have taken place at definite periods in the earth's history. Accordingly, regions of stabilized cratons and mobile orogenic belts have different pattern of mineral distribution. We are at the very earlier stage to explore the metallogenic epochs and provinces for mineral resources in the country. Some metallogenic provinces have been recognized within Nepal as uranium, copper-lead-zinc, tin-tungsten molybdenum, nickel-cobalt, goldiron-copper sulphides, magnesite-talc, limestone-dolomite, precious-semiprecious stones, gypsum-salt, petroleum-natural gas etc (ESCAP, 1993). These provinces appear to coincide more or less with the geological/ litho-tectonic zone of the Nepal Himalaya.

Localization of mineral deposits is controlled by local geological condition of particular area. It is the stratigraphy of host rocks, lithology, and geological structures like folding, faulting and igneous intrusions which determine the mineralization of the region. Rock successions formed under deep marine basins, continental margins are the sites for deposition of sedimentary ores. Permeable beds/bedding planes and fractures/joints offer ways for movement of underground fluids and thereby, they control localization of oil, gas, water and many metallic and non-metallic mineral deposits. They are also the favourable sites for replacement and contact metasomatic deposits. Impervious covers like shale, help to localize many mineral deposits beneath it and also constitute cap rocks for oil and natural gas pools. Impervious base rock likewise serves as barriers for descending fluids and help to form mineral deposits like formation of supergene sulphide and oxidised ore deposits on impervious strata. Reactive rocks like limestone, dolomite, chlorite schist, tremolite-actinolite schist are suitable sites for ore deposition. Various types of rock openings like foliation, lineation, shear zones and joints determine the immediate sites for epigenetic ore deposits. There is consistent association of 
some ores with certain types of igneous intrusions like titanoferous magnetite in Gabbro-anorthosite, corundum in nepheline syenite, tin, tungsten and uranium in granite and granitic pegmatites. According to Emmons (Kreiter, 1968), the ore deposits tend to be concentrated in the roof pendants of the batholith, in the upper parts of the stocks and in the surrounded invaded rocks, pointing to a specific control of ore localization.

\section{METALLIC MINERAL RESOURCES}

At present, several economic and sub-economic and quite a few large numbers of occurrences and showing of metallic mineral resources are known to exist in Nepal. They are represented by mineral resources of copper, lead-zinc, gold, cobalt, nickel, tungsten, tin, uranium, iron, antimony, arsenic, bismuth, cadmium, chromium, lithium, mercury, molybdenum, silver, tantalum, niobium, and titanium. Among them only five (copper, lead, zinc, uranium, iron) have been well explored that is also mainly in the Lesser Himalayan region and is evaluated as economic or sub-economic mineral deposits. Geological control for these deposits is briefly discussed.

Copper: Nepal is very rich in copper mineralization. There exist above hundred localities for copper mineralization in the country. The old mining works before 2007 B.S. were gradually discontinued due to exhaustion of easily mineable rich ore at the surface or near the surface and unavailability of new technology to continue mining at depth. From the works undertaken so far, insufficient evidences are available to draw definite conclusions on the geological nature, controls and genesis of the mineralization. On the basis of geological conditions, the copper mineralization of the country in general can be divided into three types:

1. Stratiform: It is characterized by stratified pattern and wide aerial distributions of the mineralization, a concordant sheet-like or tabular ore bodies and their simple composition like Dhusa, Devrali, Lodim Khani, Jantare Khani, Siddhi khani, etc.

2. Fault controlled hydrothermal: It is characterized by simple chalcopyrite copper mineralization in strongly sheared and crushed zone like in Wapsa, Kalitar, Chhirling Khola, Sanotar, etc.

3. Skarned type: Copper mineralization is developed at the contact zone of intrusive rock bodies and characterized by polymetallic mineralization like in Kurule, Bamangaon, Sikri khola, Kimti Khola, etc. Bhut Khola copper deposits of Tanahun is considered as a product of basic intrusion where the copper mineralization (within the boudinage of large quartzite) overlies the metabasic rocks in the region (Paudyal, 2015). In general, copper mineralization appears to be largely syngenetic (Bhattarai and Paudyal, 2018), but probably epigenetic with respect to sedimentation. Where there is a postulated major fault control, the fault either lies more or less along the geological strike or results in local metal concentration within a mineralized zone (band) of a particular stratigraphic unit. Mineralization are found confined mostly in the argillaceous or arenaceous or carbonate Pre-Cambrian rocks of Midland Group (Wapsa in Kuncha Formation, Bhut Khola in Nourpul Formation) or Bhimphedi Group (Golkhalta in Kulekhani Formation, Sanotar in massive marbles) or in biotite-garnet-kyanite schist/gneiss (e.g. in Sikpashore and Siddhi Khani copper deposits) of Himal Group. A very short description of some important copper deposits is presented in Table 1.

Lead-Zinc: Generally, the lead and zinc deposits are occurring together and so they have been described together. At present above fifty localities of lead-zinc mineralization have been discovered in Nepal. They are mostly located in dolomitic rocks of the Lesser and Higher Himalaya. Dolomite deposits are confined to certain rock units of Himal Group (Formation-II), Bhimphedi Group (Markhu Formation, Massive marbles (Bhaisedobhan ?), Phulchauki Group (Chandragiri Limestone and Godabari Marble) and in Nawakot Group (Dhadhing Dolomite). In general, disseminated, massive and vein type galena and sphalerite constitute as the ore of lead and zinc. Strong stratigraphic control of mineralization in bands parallel to bedding suggests sedimentary origin of most of the mineralization. But later on mobilization of ore fluids along pressure released areas such as along fold axis and faults show definite structural control. Lead and zinc deposits of Ganesh Himal (Lari, Suple, Serkaping and Poktanjoo) and others have been studied by several researchers (Chakrabarti, 1982; Ghimire et al., 1996; Tuladhar, 1991; Malla, 1991; and others. All have mainly suggested syn-sedimentary strata bound deposits. Ghosh et al. (2001) have determined Neoproterozoic age (785-875 Ma) age for the Ganesh Himal deposits and Paleoproterozoic (1650-1700 Ma) for the Phakuwa lead-zinc deposits of Nepal. Some characteristics features of known lead-zinc resources are presented in Table 1.

Uranium: In Nepal, occurrences of uranium mineralization has been recorded from granitic and gneissic rocks of Higher Himalaya, Late Tertiary rocks successions of Sub-Himalaya, Thakkhola-Mustang Graben and Banku Quartzite (Bhimphedi Group?) of the Lesser Himalaya, Far western Nepal. Within the Siwalik rocks in the central Nepal, visible showings of uranium mineralization has been recorded from the Upper Middle Siwalik (UMS) and basal/ lower parts of Upper Siwalik (US) in Buka Khola, Chiruwa Khola, Chandi Khola, Tinbhangale Khola, Mardar Khola, and Panpa Khola areas (Kaphle and Khan, 1990, 2003). Among them significant mineralization has been recorded only from Tinbhangale area. Mineralization is restricted within pebbly arkosic sandstone bed of Upper Middle Siwalik. It is generally associated with some rusty-yellow limonitic layers and represented by tyuyamunite and coffinite. Similar sandstone type uranium mineralization has been also recorded from the late Tertiary graben sediments of Upper Mustang area (Lomanthang). Uraninite and autonite mineralization has been recorded from Banku Quartzite of Bajhang (Nimli Gad) and Baitadi area (Jamari Gad, Bangabagar-Baggot, Gorang). Among 
Table 1: Characteristics features of some important metallic resources of Nepal

\begin{tabular}{|c|c|c|c|c|}
\hline Resources & Locality & $\begin{array}{l}\text { Characteristic feature/ } \\
\text { Host rock units }\end{array}$ & Special remarks & $\begin{array}{l}\text { Examples of } \\
\text { similar deposits }\end{array}$ \\
\hline \multirow[t]{3}{*}{ Copper } & Dhusa & $\begin{array}{l}\text { Simple chalcopyrite and pyrite } \\
\text { mineralization occurring in several } \\
\text { horizons in phyllite, dolomite, slate and } \\
\text { quartzite of Nawakot Group }\end{array}$ & $\begin{array}{l}\text { Small deposits stratiform } \\
\text { (Nawakot Group) }\end{array}$ & $\begin{array}{l}\text { Devrali, } \\
\text { Bhutkhola, } \\
\text { JantareKhani, } \\
\text { LodimKhani }\end{array}$ \\
\hline & Kalitar & $\begin{array}{l}\text { Chalcopyrite, chalcocite and magnetite } \\
\text { occur as small pods of massive ore and } \\
\text { dissemination in Kulekhani Quartzites in } \\
\text { a belt of intense shearing and crushing } \\
\text { more or less following the bedding }\end{array}$ & $\begin{array}{l}\text { Sub-economic deposit, fault } \\
\text { controlled hydrothermal }\end{array}$ & $\begin{array}{l}\text { Chhirling, } \\
\text { Sanotar }\end{array}$ \\
\hline & Kurule & $\begin{array}{l}\text { Chalcopyrite with massive pyrrhotite \& } \\
\text { Pyrite in quartizic phyllite and quartzite } \\
\text { and skarn gangue minerals developed at } \\
\text { exo-contact of granitic gneisses/granites }\end{array}$ & $\begin{array}{l}\text { Sub-economic skarn } \\
\text { deposits }\end{array}$ & $\begin{array}{l}\text { Bamangaon, } \\
\text { Sikri Khola, } \\
\text { KhimtiKhola }\end{array}$ \\
\hline \multirow[t]{2}{*}{ Lead-Zinc } & $\begin{array}{l}\text { Ganesh } \\
\text { Himal, }\end{array}$ & $\begin{array}{l}\text { Mineralization confined to crystalline } \\
\text { dolomite/ limestone (Himal Group, } \\
\text { Formation-II), galena, sphalerite with } \\
\text { chalcopyrite, pyrite occurs in } \\
\text { disseminated, massive and vein types in } \\
\text { planar zone. }\end{array}$ & $\begin{array}{l}\text { Small economic stratabound } \\
\text { (sedimentary) }\end{array}$ & $\begin{array}{l}\text { Phakuwa, } \\
\text { Phulchauki, } \\
\text { Khirauli }\end{array}$ \\
\hline & $\begin{array}{l}\text { Labang- } \\
\text { Khairang }\end{array}$ & $\begin{array}{l}\text { Disseminated, massive and stringers of } \\
\text { galena and sphalerite confined in marbles } \\
\text { of Markhu Formation (Bhimphedi } \\
\text { Group) }\end{array}$ & $\begin{array}{l}\text { Sub-economic } \\
\text { (sedimentary) }\end{array}$ & $\begin{array}{l}\text { Pangunm,Damar, } \\
\text { Kolchebang, } \\
\text { Sollendada, } \\
\text { Kandebas }\end{array}$ \\
\hline Uranium & $\begin{array}{l}\text { Tinbhangale } \\
\text { (Makwanpur) }\end{array}$ & $\begin{array}{l}\text { Tyuyamunite and coffinite mineralization } \\
\text { within pebbly arkosic sandstone of Upper } \\
\text { Middle Siwalik and Upper Siwalik, } \\
\text { associated with rusty-yellow limonitic } \\
\text { layer }\end{array}$ & $\begin{array}{l}\text { Sub-economic- sedimentary } \\
\text { (sandstone type) }\end{array}$ & $\begin{array}{l}\text { Chandi Khola } \\
\text { Chiruwa Khola } \\
\text { etc. }\end{array}$ \\
\hline \multirow[t]{4}{*}{ Iron } & $\begin{array}{l}\text { Phulchauki } \\
\text { (Lalitpur) }\end{array}$ & $\begin{array}{l}\text { Laminated, pisolitic fossiliferous } \\
\text { hematite bands are confined to Chitlang } \\
\text { Slate of Silurian age. }\end{array}$ & $\begin{array}{l}\text { Economic sedimentary } \\
\text { (Silurian) }\end{array}$ & \\
\hline & $\begin{array}{l}\text { Thoshe } \\
\text { (Ramechhap) }\end{array}$ & $\begin{array}{l}\text { Bands of specularitic hematite and rarely } \\
\text { magnetite ore are confined to } \\
\text { phyllite/schists and quartzite succession } \\
\text { of Lesser Himalayan Crystalline } \\
\text { (Bhimphedi Group, Pre-Cambrian) }\end{array}$ & $\begin{array}{l}\text { Sub-economic } \\
\text { sedimentary/metamorphosed } \\
\text { (Pre-Cambrian) }\end{array}$ & Jelbang (Rolpa) \\
\hline & $\begin{array}{l}\text { Labdi Khola- } \\
\text { Bhut Khola }\end{array}$ & $\begin{array}{l}\text { Thin bands of hematite ore confined to } \\
\text { the rocks of the Nourpul Formation (Pre- } \\
\text { Cambrian) }\end{array}$ & $\begin{array}{l}\text { Sub-economic } \\
\text { metamorphosed- } \\
\text { sedimentary (Pre-Cambrian) }\end{array}$ & $\begin{array}{l}\text { By genesis it } \\
\text { appears more or } \\
\text { less Similar to } \\
\text { Thoshe deposit }\end{array}$ \\
\hline & $\begin{array}{l}\text { Dhaubadi } \\
\text { (Nawalparasi) }\end{array}$ & $\begin{array}{l}\text { Oolitic Hematite mineralized beds } \\
\text { confined to lower Tertiary rock units of } \\
\text { Melpani Formation }\end{array}$ & $\begin{array}{l}\text { Sub-economic sedimentary } \\
\text { (lower Tertiary) }\end{array}$ & $\begin{array}{l}\text { Bhainsekati } \\
\text { (Palpa) }\end{array}$ \\
\hline
\end{tabular}

them Gorang mineralization is more prominent and fairly rich in uranium with few primary gold, pyrite and chalcopyrite.

Iron:Small scale domestic mining and smelting of iron ores using primitive furnaces have been practiced in Nepal since time immemorial. There exists large number of iron ore occurrences mainly confined to three stratigraphic levels: late Pre-Cambrian, Silurian and lower Tertiary. Most of them represent sedimentary metamorphosed hematite-magnetite type of deposit. Major known iron deposits are Phulchauki, Those,
LabdiKhola-BhutKhola, Jelbang, Bhedikhor-Ransing, Lukarban and Dhauwadi-Pokhari. The Phulchauki iron deposit is confined to Chitlang Slate of Silurian age is represented by banded hematite ore with thinly laminated, pisolitic and fossiliferous nature. Initially, it has been studied by Malla (1991) and Suwal (1991). Thoshe iron deposits has been studied by Kaphle (2011), Kaphle and Khan (2006) and others. Mineralization occurs in three horizons composed of magnetite, specularitic hematite and confined to phyllites/schists and quartzites of the Lesser 
Himalayan crystalline (Bhimphedi, late Pre-Cambrian). Jelbang (Rolpa) mineralization is more or less similar to Thoshe. Iron mineralization in the Labdi Khola- Bhut Khola area is represented by thin hematite/magnetite bands confined to the rocks of the Nourpul Formation as syngenetic deposit and iron deposit of Phalamdada of Tanahun is represented by limonite deposits confined at the upper part of the Nourpul Formation (Paudyal, 2015). Sedimentary iron ore deposit of Dhauwadi-Pokhari area is an oolitic hematite and confined to lower Tertiary succession of Lesser Himalaya. It is one of the big iron ore deposits which has quite long extension of over $5 \mathrm{~km}$ or so and it may continue further west to Palpa.

\section{NONMETALLIC MINERAL RESOURCES}

Nepal is very rich in non-metallic resources. At present economic to sub-economic deposits of twenty types of nonmetallic mineral resources are known from different parts of Nepal. They are mostly categorized as (a) industrial rocks and minerals like limestone, dolomite, magnesite, phosphorite, talc, mica, clays, common salts, feldspars, pyrite, silica sand etc.(b) gem stones like ruby, sapphire, tourmaline, aquamarine/beryl, amazonite, garnet, kyanite, amethyst, quartz crystals, (c) Decorative stones and construction materials like granite, marble, syenite, quartzite, dolomite, slate, gravel, sand etc.; (d) Energy/Fuel minerals like uranium, coal, oil and natural gas. Details of the geological controls of some important deposits are briefly discussed below and they are summarized in Table 2.

\section{Industrial Rocks and Minerals}

Clays: Economic deposits of clays are represented by kaolin and red clays. Kaolin deposits are developed by deep weathering of early Palaeozoic Palung Granites at Naliban, Kharkha, Panchmane, Dalchap and Daman area. Such depositsare scattered, forming pockets and extending down deep upto a depth of $15 \mathrm{~m}$. The weathering is more pronounced near the joints, fissures, cracks and roots of trees, where infiltration of water is easy.

Deposits of red clays have been recorded from different parts of Nepal and they are developed due to deep weathering of exposed rocks, colluviums and alluviums. In Lamasure (Makwanpur) the red clay is developed over old terrace underlainby Siwalik succession in Hetauda area. Red clays deposits are also known from Nawakot, Kavre, Nawalparasi, Surkhet, and many other districts are 5 to $-15 \mathrm{~m}$ thick and high in aluminium and iron content. Red clay is suitable as a mixture in limestone to make clinker for the cement production.

Common salts: Salt in the form of brine water and encrustation have been recorded from several localities of Mustang, Manang, Dolpa and Lamjung district inTethys zone (Narsing Khola, Chhidi Khola, Chharkhabhot, Bhulbhule, Darimbot and other places). In Narsing Khola, salt incrustation occurs in highly jointed and fractured limestone. The brine solution of this area contains about $3 \% \mathrm{NaCl}$ and $1 \% \mathrm{KCl}$ whereas the salt incrustation constitutes about $72.84 \% \mathrm{NaCl}$,
$24.54 \% \mathrm{KCl}$ and $97.80 \%$ of total chloride. In Narsing Khola, Mutsng some salt mining from brine water was carried out till last decade for local consumption. However, annual salt production was below $25 \mathrm{mt} /$ year.

Dolomite: Documentation of industrial dolomite is either lacking or sketchy. Good quality dolomites have been observed in association with the limestone deposits at Dhankuta, Udaypur, Makwanpur, Baitadi, Bajhang, Bajura, Surkhet, Salyan,Dang, Rolpa, Arghakhanchi,Palpa, Syangja, Kavre, etc. (DMG, 2004). Kaphle, (2005); Sthapit (1976, 1978); Madhikarmi(2003); Khadka (2007); Pant (2007) and others have also reported dolomite and limestone deposits. Economic deposits of dolomite have been found at Sindhali (Udaypur) occurring within PreCambrian Bhainse Doban Marble (Trijuga Formation) of Bhimphedi Group (Sah et al., 2003). It represents a small deposit (Walter and Werner, 2003) having 4.2 million tons of good quality dolomite. Recorded dolomites occurrences have been reported from rock successions of Dhading Dolomite, Kerabari Dolomite, Ripa Member of Sorek Formation and other successions of Midland Group. Huge dolomite deposits are reported from Lesser Himalaya as well as from Tibetan Tethys (Kaphle, 2005).

Magnesite: Several Magnesite occurrences have been recorded within the Jhiku Carbonate rocks of Nawakot Group or their equivalent rocks of Lesser Himalaya. Most of the occurrences aresmall, isolated and irregular or lensoid bodies generally interfingering with the dolomite of calc-phyllite rock units. The Kharidhunga Magnesite of Dolkha and Kampughat Magnesite in Udaypur are the only two deposits that have been proven to be exploitable. Mining, processing and making dead burnt magnesite bricks from Kharidhunga Magnesite deposit was in trial production before but it is not in operation since long time. Both deposits have been considered to sedimentary or metasedimentary origin (Mandal, 1998; Khatri, 1973).

Cement Grade Limestone: Several researchers have studied the cement grade limestone of Nepal (Joshi et al., 1994; Khatri et al., 1979; Shrestha, 2002; Karmacharya, 2003, 2005; Madhikarmi, 2003; Jnawali, Pant, 2003, 2006, 2007; Khadka, 2007; Sah et al., 2003). Large number of cement grade limestone deposits has been recognized from the rock succession of Late Pre-Cambrian to Eocene age. Several cement industries are mining some of these deposits. They are generally confined to mostly seven-stratigraphic units of Nepal Lesser Himalaya. BhainseDobhan Marble (Bhainse, Sindhali, Majuwa), Markhu Formation (Trikhandi limestone), Jhiku Carbonate Beds (Jogimara limestone, Ahalephaka limestone, Galtar, Dhanpure limestone, Dhundada-Devisthan limestone); Kerabari Formation (Kerabari limestone, Khursandi limestone, Madhuban limestone); Chandragiri limestone (Chobhar, Rossi, Mane) and Eocene Beds (Gandari). They all contain Cao $>43 \%$ and $\mathrm{MgO}<3 \%$ in average which is quite suitable to manufacture ordinary portland cement.

Phosphorite: Phosphorite is an important raw material for manufacturing chemical fertilizer. So far, some low grade 
Table-2: Summary of some important Non-metallic mineral deposits of Nepal

\begin{tabular}{|c|c|c|c|c|}
\hline Resources & Locality & Characteristic feature & Special remarks & $\begin{array}{l}\text { Examples of similar } \\
\text { deposits }\end{array}$ \\
\hline Kaolin Clays & Naliban, Kharka & $\begin{array}{l}\text { Developed due to intense deep weathering of } \\
\text { early Paleozoic granites }\end{array}$ & $\begin{array}{l}\text { Weathering, sub- } \\
\text { economic deposit }\end{array}$ & $\begin{array}{l}\text { *Panchmane, } \\
\text { *Dalchap, *Daman }\end{array}$ \\
\hline Red Clays & $\begin{array}{l}\text { Lamsure } \\
\text { (Makwanpur) }\end{array}$ & $\begin{array}{l}\text { Developed due to intensive weathering over old } \\
\text { terrace deposits underlain by Siwalik succession } \\
\text { in Hetauda area }\end{array}$ & $\begin{array}{l}\text { Weathering, } \\
\text { Economic } \\
\text { deposit }\end{array}$ & $\begin{array}{l}\text { Chidika, Beltar } \\
\text { Salghari, Mauna } \\
\text { Budhak, Guttu, Golche } \\
\text { Khola }\end{array}$ \\
\hline Common salt & Narshing Khola & $\begin{array}{l}\text { Salt in the form of brine water and salt } \\
\text { encrustation occur in the highly jointed and } \\
\text { fractured limestone of Tethys zone. }\end{array}$ & $\begin{array}{l}\text { Small deposits } \\
\text { Mining brine } \\
\text { water deposit }\end{array}$ & $\begin{array}{l}\text { Chhidi Khola, } \\
\text { Chharkabot }\end{array}$ \\
\hline Dolomite & Sindhali (Udaypur) & $\begin{array}{l}\text { Dolomite associated with Sindhali Limestone of } \\
\text { Trijuga Formation (= Bhainse Dobhan Marble of } \\
\text { Bhimphedi Group) }\end{array}$ & $\begin{array}{l}\text { Small deposit, } \\
\text { sedimentary }\end{array}$ & Madhuban, Chiuri \\
\hline Magnesite & $\begin{array}{l}\text { Kharidhunga } \\
\text { (Dolakha) }\end{array}$ & $\begin{array}{l}\text { Developed in graphitic phyllite. Possibly } \\
\text { representing Jhiku Carbonate Beds of } \\
\text { NawakotGroup? Magnesite is of crystalline } \\
\text { breunnerite type. }\end{array}$ & $\begin{array}{l}\text { Economic } \\
\text { metamorphic } \\
\text { sedimentary }\end{array}$ & $\begin{array}{l}\text { *Kampughat, *Phaplu, } \\
\text { *Kubhide }\end{array}$ \\
\hline Phosphorite & Dhikgad (Baitadi) & $\begin{array}{l}\text { Phosphorite horizons occurs in massive cherty } \\
\text { dolomite associated with stromatolite. } \\
\text { Mineralization is in form of stromatolitic layers, } \\
\text { phosphatic pellets or in laminated massive bed. }\end{array}$ & $\begin{array}{l}\text { Shallow marine } \\
\text { sedimentary sub- } \\
\text { economic }\end{array}$ & $\begin{array}{l}\text { *Junkuna, *Sangaon, } \\
\text { *Morgaon } \\
\text { *Dhaubisaune } \\
\text { *Tarugad, *Juligad, } \\
\text { *Goichan, *Kadachaur }\end{array}$ \\
\hline Pyrite & Bearing Khola & $\begin{array}{l}\text { Pyrite, Pyrrhotite with chalcopyrite, sphalerite, } \\
\text { galena and occurs in band within calc-mica } \\
\text { schists of Ilam Metamorphic Group as } \\
\text { disseminated or massive ores }\end{array}$ & $\begin{array}{l}\text { Stratabound, sub- } \\
\text { economic }\end{array}$ & \\
\hline Silica sand & Karra khola & $\begin{array}{l}\text { Silica sands developed within the alluvial plain of } \\
\text { KarraKhola in Hetauda area, underlained by } \\
\text { Siwalik succession. }\end{array}$ & $\begin{array}{l}\text { Alluvium of } \\
\text { KarraKhola }\end{array}$ & $\begin{array}{l}\text { *DudhauraKhola, *Pasa } \\
\text { hKhola }\end{array}$ \\
\hline Talc & $\begin{array}{l}\text { Kharidhunga } \\
\text { (Dolakha) }\end{array}$ & $\begin{array}{l}\text { Developed in association with magnesite within } \\
\text { Jhiku Carbonate Beds of Nawakot Group. } \\
\text { Mineralization mostly developed in pockets }\end{array}$ & $\begin{array}{l}\text { Mining, } \\
\text { stratiform/ } \\
\text { hydrothermal }\end{array}$ & *Phaplu, *Selankatti \\
\hline $\begin{array}{l}\text { Ruby and } \\
\text { sapphire }\end{array}$ & $\begin{array}{l}\text { Ganesh Himal (Lari- } \\
1 \text {, Rasuwa) }\end{array}$ & $\begin{array}{l}\text { Ruby and sapphire mineralization is developed } \\
\text { within dolomitic marbles of Higher Himalaya } \\
\text { (Possible Formation II) }\end{array}$ & $\begin{array}{l}\text { Stratiform/ } \\
\text { hydrothermal, } \\
\text { subeconomic }\end{array}$ & *Chumar, ${ }^{*}$ Ruyal \\
\hline $\begin{array}{l}\text { Tourmaine/ } \\
\text { Aquamarine } \\
\text { (Beryl) }\end{array}$ & $\begin{array}{l}\text { Hyakule } \\
\text { (Sankhuwasabha) }\end{array}$ & $\begin{array}{l}\text { Tourmaline/aquamarine mineralization occurs in } \\
\text { complex zoned pegmatite at the vicinity of MCT. }\end{array}$ & $\begin{array}{l}\text { Subeconomic } \\
\text { pegmatitic } \\
\text { (Residual } \\
\text { magma) }\end{array}$ & *Phakuwa, *Naje \\
\hline Kyanite & Daha (Jajarkot) & $\begin{array}{l}\text { Occurs in high-grade metamorphic schist and } \\
\text { gneisses in the Higher Himalaya (Himal Gr.) }\end{array}$ & $\begin{array}{l}\text { Metamorphic, } \\
\text { mining }\end{array}$ & *Suneri \\
\hline $\begin{array}{l}\text { Quartz } \\
\text { crystals }\end{array}$ & Khejemi (Taplejung) & Quartz crystals occurs in pegmatites & $\begin{array}{l}\text { Pegmatitic, } \\
\text { economic, } \\
\text { mining }\end{array}$ & *Raluka, *Dwari \\
\hline \multirow[t]{3}{*}{$\begin{array}{l}\text { Cememt } \\
\text { Grade } \\
\text { Limestone }\end{array}$} & Sindhali (Udaypur) & $\begin{array}{l}\text { Thick band of crystalline limestone (CaO } 52 \% \text {, } \\
\text { MgO } 1.5 \% \text { ) occurs within Bhimphedi Group and } \\
\text { represent Trijuga Formation (= Bhainse Dobhan } \\
\text { Marble) }\end{array}$ & $\begin{array}{l}\text { Economic } \\
\text { deposit mining, } \\
\text { late Pre- } \\
\text { Cambrian }\end{array}$ & *Bhainse, *Majuwa \\
\hline & Jogimara (Dhading) & $\begin{array}{l}\text { Thick band of bedded limestone confined to } \\
\text { Jhiku Carbonate Beds of Benighat Slate with } \\
\mathrm{CaO} 53.79 \% \text { and } \mathrm{MgO} 1.29 \%\end{array}$ & $\begin{array}{l}\text { Economic late } \\
\text { Pre-Cambrian }\end{array}$ & \\
\hline & Chovar (Lalitpur) & $\begin{array}{l}\text { Thick band of Limestone confined to early } \\
\text { Paleozoic Chandragiri Limestone (CaO } 47.93 \% \text {, } \\
\mathrm{MgO} 1.29 \%)\end{array}$ & $\begin{array}{l}\text { Economic, } \\
\text { mining } \\
\text { postponed }\end{array}$ & $\begin{array}{l}\text { *Rossi, } \\
\text { *Mane }\end{array}$ \\
\hline Marble & $\begin{array}{l}\text { Godavari Marble } \\
\text { (Lalitpur) }\end{array}$ & $\begin{array}{l}\text { White, pink, greenish, grey and dark grey } \\
\text { crinoidal marbles confined to Devonian Godavari } \\
\text { Formation }\end{array}$ & $\begin{array}{l}\text { Economic, } \\
\text { mining } \\
\text { postponed }\end{array}$ & \\
\hline Coal & Tosh (Dang) & $\begin{array}{l}\text { Three horizons of bituminous coal is developed } \\
\text { within shale and sandstone succession of Lower } \\
\text { Tertiary (Tosh Group) }\end{array}$ & $\begin{array}{l}\text { Economic, } \\
\text { mining }\end{array}$ & $\begin{array}{l}\text { *Siuja } \\
\text { *Chhap } \\
\text { *Kapurkot (Salyan) } \\
\text { *Devgir (Palpa) }\end{array}$ \\
\hline Oil and Gas & $\begin{array}{l}\text { Teku and few other } \\
\text { places (Kathmandu } \\
\text { Valley) }\end{array}$ & $\begin{array}{l}\text { Natural gas mainly consisting methane }(75-80 \%) \\
\text { occurring as marsh gas dissolved in water type } \\
\text { originating from fluvio-lacustrine sediments of } \\
\text { Kathmandu Valley }\end{array}$ & Economic & $\begin{array}{l}\text { *Jhawani (Southern } \\
\text { bank of Rapti, } \\
\text { Chitwan) }\end{array}$ \\
\hline
\end{tabular}


phosphorite deposits and few occurrences have been identified in the country. Sub-economic stromatolitic phosphorite deposits have been recognized fromDhik Gad, Junkuna, Morgaon, Sangaon area inBaitadi (Bashyal, 1980, 1982, 1985) and Tarugad, Juilgad and Goichan and Kadachaur area in the Bajhang District of Farwestern Nepal, where phsosphorite are associated with Pre-Cambrian cherty stromatolite dolomite beds. Several occurrences have been recognized from the Gondwana succession in Barahakshetra, Takure, Tawa Khola area in eastern Nepal (Bashyal, 1985; ESCAP, 1993) and few other places in Sewar Khola, Dang and in the vicinity of the Main Boundary Thrust (Kaphle, 1979).

Pyrite: A present several occurrences of pyrite mineralization has been recorded from Makwanpur, Dhadhing, Rasuwa, Ilam, Dadeldhura, Bajhang, Darchula, Rolpa, and other districts of Nepal (DMG, 2004). A sub-economic deposit of pyrite has been reported in Bearing Khola of Ilam district. Mineralization is stratigraphically controlled and it is confined to a band within calc-mica schist unit of Ilam Metamorphic Group (Kaphle and Khan, 2007). Mineralization is represented by pyrite, pyrrhotite with chalcopyrite, sphalerite, galena, and magnetite occurring in disseminated or massive form recrystallized during regional metamorphism. Later detail study by Kaphle and Khan in 2007 confirmed that the mineralization of Bearing Khola has been considered as polymetallic sulphide ore deposits which is a sub-economic deposit.

Silica sand: Few occurrences of silica sands (DMG, 2004) have been recognized from the Makwanpur, Bara and Kathmandu district of Nepal. However, economic deposit of silica sand has been established only from Karra Khola in Hetauda area (Makwanpur). It contains about $94-97 \%$ of silica and developed within the flood plain deposits of the Karra Khola underlined by Siwalik rock succession.

Talc: Occurrences of talc have been reported from more than 20 locations of the country (DMG, 2004). The biggest occurrence is associated with the magnesite at Kharidhunga, which is presently being mined. Mineralization is possibly confined to the Jhiku Carbonate Beds of the Benighat Slate of the Nawakot Group. A 10,000 tpa grinding and pulverising plant to make talcum powder exists at Lamosangu.

\section{Gem Minerals (Gemstones)}

Occurrences of gemstones are known mainly from pegmatites of the Higher Himalayan regions of Nepal. Recorded gem minerals include Ruby, Sapphire, Topaz, Tourmaline, Aquamarine, Beryl, Garnet, Quartz crystals, Spinel, Kyanite, amazonite and few others. Some of them are being mined and shortly discussed below.

Ruby and Sapphire: The ruby and sapphire mineralization have been recorded from Lari valley of Ganesh Himal (Rasuwa) and from Chumnar and Ruyil in the Dhadhing District, and Shelghar, and Pola area of thd Rashuwa District (Bassett, 1987; DMG, 1993; Kaphle, 2011). In Ganesh Himal, the mineralization occurs in highly tectonized sacchoroidal dolomite of Higher Himalayan Crystalline (Possible Formation - II). The ruby is light red to red in colour and the sapphire is light to dark blue and in general they are small crystals (1 to several $\mathrm{mm}$ ). Spinel has been also recorded from the Ganesh Himal (Uhlir et al., 1998)

Tourmaline and Aquamarine (Beryl): There exist several prospects for tourmaline and aquamarine gemstones like in Hyakule, Phakuwa, Naje, Langtang valley, Tikachaur, Lekhpatan, Garkhakot, Ikhabu, Lodantar,Namsaling and few others. All the tourmaline and aquamarine prospects occur in pegmatites with or without discordant relation to the country rocks of highgrade metamorphic rock sequence in the vicinity of the Main Central Thrust (MCT). Hyakule and Phakuwa have yielded virtually the entire gem tourmaline and aquamarine of the country. Five distinct mineral species of tourmaline group (schorlite, dravite, elbaite, uvite and liddicoatite) occur in Nepal (Bassett, 1987, 1979). Aquamarine is quite widespread in occurrence but is seldom of gem quality. According to Einfalt et al. (1995) the gem pegmatites can be distinguished from the barren gem pegmatite with high content of $\mathrm{Rb}, \mathrm{Cs}, \mathrm{MnO}, \mathrm{Ta}$ and $\mathrm{Sn}$ and lower ratio of $\mathrm{Mg} / \mathrm{Li}, \mathrm{K} / \mathrm{Rb}$ and $\mathrm{K} / \mathrm{Cs}$ in muscovite.

Kyanite: Kyanites are present in high-grade metamorphic schist and gneisses in the Higher Himalayan region. They are known from Dolakha, Sankhuwasabha, Taplejung, Rasuwa, Nawakot, Sindhupalchok, Dhading, Bajhang, Jajarkot and Achham Districts. Elongated tabular,inky blue kyanite crystal are cut for gems. They are also used to manufacture spark plugs and other highly refractory porcelains. Four small-scale kyanite mines are in operation in Daha, and Suneri areas in Jajarkot and Barah area of Achham District (Kaphle, 2011).

Garnets: Almost all the prospective garnet are recovered from strongly tectonized lenses and pods of chlorite-biotitegarnet-schist within high grade metamorphic rock sequence of Higher Himalayan regions. Deep red or red coloured almandine, hessonite and pyrope garnet are mined in Sankhuwasabha and Taplejung Districts. Due to highly fractured nature only selected pieces are cut for gem and rest are generally used to make beads and abrasive powder.

Quartz crystals (Rock crystal): Quartz crystal are known from the pegmatites located in different parts of Taplejung, Ilam, Sankhuwasabha, Nuwakot, Dhading, Rasuwa, Manang, Dailekh, Jajarkot and Darchula Districts. Smoky quartz crystal, rose/pink quartz (amethyst), yellow quartz (citrine) and colourless perfect clear crystal (rock crystal) are the gem variety that are available in Nepal. They are suitable to cut and polish for gems. Two small scale quartz crystal mines are in operation one at Khejemi (Taplejung) and another in Raluka (Nuwakot).

\section{Decorative Stones and Construction Materials}

Nepal is very rich in decorative stones and construction materials. The main construction materials available in Nepal are river bed gravel deposit and bed rock deposits which are 
widespread and visible resources all over the country. The major rock types used in dimension stone and decorative stones include limestone, dolomite, marble, granite, quartzite, basic rock, sandstone and slate. A brief description of geological control of cement grade limestone (as described above), marble and roofing slate has been presented below.

Marble: In Nepal, several researchers (Shrestha, 2003; Ghimire and Napit, 2005; Ghimire and Dhakal, 2006, 2007) have studied the marbles, granite, quartzite and some basic rocks to cut into blocks or slabs and polish them to use as decorative stones and dimension stones. But only very few deposits have been recognized however, several occurrences have been identified. Identified rock units suitable for polishing include Palung and Ipa granites, Godavari marble, Bhimsen marble (Kalitar Formation), Bhainse Dobhan marble, Markhu marble and Amphibolite and white quartzite of the Robang Formation. Among these, Godavari marble confined to Devonian rock succession of the Phulchauki Group was mined by Godavari marble industries (now not in operation). Similarly mining of marble from Kavrepalanchok by Everest marble industries are also in operation. Marble deposit is being extracted by open cast mining method by private companies and producing marble slab, chips and aggregates.

Roofing Slate: In Nepal there exist several stratigraphic units containing slates that can be mined as roofing stones (Benighat slate, Dadagaon phyllite, Nourpul Formation, Robang Formation, Patan Slate and others (Sah, 2015)). Cratons et al. (2016) had made technological characterization of roofing slates from Benighat and Nourpul Formations. Karki and Paudel (2016) have studied the Bandipur Slate (Nourpul Formation) of the Tanahu District. Slates are the common roofing and pavement materials in the mountain regions of the country. They are available in many parts of the country and are extensively mined in Taplejung, Okhaldhunga, Dhankuta, Sindhupalchok, Nuwakot, Tanahu, Dhading, Syangja, Parbat, Baglung, Pyuthan, Rolpa, Jajarkot, Rukum, Achham, Bajhang, Bajura, Dadeldhura, Baitadi, Darchula and in many other districts of Nepal.

\section{FUEL/ ENERGY MINERAL RESOURCES}

In Nepal, occurrences of fuel resources are represented by coals, oil and natural gas and radioactive minerals (described above).

Coal: Coal resources are confined to three stratigraphic units in Nepal. They are Gondwana coal, Tertiary coal and Quaternary lignite deposits of Kathmandu valley. Gondwana coal has been reported from Lower Gondwana sediment of Barahchhetra, Takure and Tawa Khola area of eastern Nepal. Lower Tertiary coals are mining from Dang, Sallyan, Palpa and Rolpa Districts. of western Nepal and they are well studied by Aryal and Shrestha (2003), Aryal (2003), Aryal and Shrestha (2005), Sah et al (2003), Paudyal and Sah (2014). The lower Tertiary coals are developed in three horizons at the Tosh area of Dang within shale/sandstones succession of the Tosh Group.

Oil and gas: A series of oil and gas seeps ( $>40$ seeps) are located beneath Pre-Cambrian rocks in Dailekh region of western Nepal. It includes Sirasthan, Nabisthan, Padukasthan and few others nearby places. According to CPIT (1973) these oil and gas seeps possibly represent crude oil coming from unmetamorphosed beds at depth (Tertiary sedimentary rocks) and also there are some possibilities to find oil and natural gas in the southern part of the country. Analysing the geological conditions of the southern part of the country (underlying Tertiary Pre-Siwalik rocks named as Unknown Formation lying at depth in the Terai Plain area and Siwalik rocks), Bashyal (1998) and Jnawali (2009) clarified the presence of source, seal and reservoir rocks together with the various traps. They have also mentioned that some sandstone of the Melpani Formation (Lower Tertiary) bear solid hydrocarbon which is the indication of oil reserves.

Natural gas seeps are also known from Muktinath, in Mustang (DMG, 2004). One can still see burning gas inside the temple there. It has yet to be studied in detail about the source and possible reserve.

An economic deposit of methane gas reserve of $160,000,000$ cubic meter has been recognized from different parts of Kathmandu valley. Fourteen gas wells were developed in Teku, Tripureshor, Bhrikutimandap, Imadole, Tinkune, Jaributi office and few other areas to obtain the gas for household purpose.But at present none of them are in operation. All these gas deposits are of dissolved in water type and originated from fluvio-lacustrine sediments (Shrestha and Dangol, 2007). It represents a kind of Marsh gas. Similar gas seepage has been also recorded from the fluviate deposits at Jhawani, about 60 $\mathrm{km}$ west of Hetauda at the southern bank of Rapti River (CPIT, 1973).

\section{DISCUSSION AND CONCLUSION}

Analysis of geological controls on economic and subeconomic deposits shows that they are either syngenetically or epigenetically confined to particular stratigraphic units. The mineralization occurs in band and follows the bedding or foliation plane and confined to certain stratigraphic units. They can be considered as stratabound or stratiform type. Epigenetic deposits are related to certain events of crustal movement in time and spaces and are related to certain metallogenic epochs. Most of the epigenetic deposits are related to Pre-Cambrian, early Paleozoic or Late Cainozoic metallogenic epochs in Nepal.

The detail geological mapping based on formal stratigraphic units is necessary to access the geological control and spatial distribution of mineral deposits in the country and it is vital for future prospecting and exploration of mineral resources in Nepal. The random prospecting is not of scientific and never be well settled job of mineral prospecting. Therefore, the first step of preparation of geological map with formal stratigraphic units is the prime duty of mineral prospecting 
geologists and mineral promoting organizations.

Nepal should develop strong data base in the field of geology to explore the mineral resources. Application of geochemical and geophysical techniques count heavily in mineral exploration in addition to surface geological works. Likewise, analysis of water resources will greatly help to understand the nature of mineralization underneath. It would be a good step to prepare a new upgraded geological map in collaboration with Tribhuvan University/ Central Department of Geology (CDG) and Department of Mines and Geology (DMG) with proper consideration of long-term and research-based investigation. Most of existing maps of Departments of Mine and Geology (DMG) bears informal rock units. There is urgent need to formalize them as mineral resources are confined to particular stratigraphic units. Therefore, standard stratigraphy of the country should be well known and precisely worked out and must be followed by all the geologists. It is vital for the preparation of standard geological maps and also for the development of mineral resources of the country.

\section{ACKNOWLEDGEMENT}

Authors are very thankful to Prof. Dr. Lalu Prasad Paudel and other staff members of Central Department of Geology for their encouragements and suggestions provided in preparing the manuscript. We are also much thankful to organizing committee of 9th Nepal Geological Congress for providing an opportunity to deliver the content of this manuscript in the congress.

\section{REFERENCES}

Aryal, R.K., 2002, Current status of coal deposits of Nepal. Bull. Nep. Geol. Soc., v. 17, pp. 77-80.

Aryal, R.K., 2003, Coal occurrences in Harthok-Mujhun area of western Palpa. Dept. of Mines and Geology, Annual Report, no.1, pp. 63-67.

Aryal, R.K. and Shrestha, U.B., 2005, Coal occurrences in Tosh-Seuza area of Dang district, Mid-Western Nepal. Dept. of Mines and Geology, Annual Report, no. 2, pp. 39-43.

Bashyal, R.P., 1980, Gondawana type of formation with phosphatic rocks in south-eastern Nepal.Jour. Geol. Soc. India, v. 21(10), pp. 484-491.

Bashyal, R.P., 1985, A preliminary appraisal of Baitadi phosphorite, far western Nepal. Jour. Nep. Geol. Soc., v. 3 (1 and 2), pp. 13-19.

Bashyal, R.P., 1998. Petroleum exploration in Nepal. Jour. Nep. Geol. Soc., v. 18 (Sp. Issue), pp. 19-24.

Bashyal, R.P., 1982, Stromatolitic phosphorites of far western Nepal. Jour. Nep. Geol. Soc., v. 2, pp. 39-46.

Basset, A.M., 1978. Nepal Gems: Tourmalines.Jour. Nep. Geol. Soc., v. 4 (1\&2), pp. 31-41.
Bassett, A.M., 1979, Hunting of gemstones in the Himalayas of Nepal. Lapidary Journal, v. 33, No. 7, pp. 1492-1520.

Bhattarai, A. and Paudyal, K.R. 2018, Geology and mineral resources of Phalamdada-Dhuwakot section of westcentral Nepal, Lesser Himalaya. Bulletin of Dept. of Geology, Tribhuvan University, Kathmandu, Nepal, v. 20, pp. 59-64. https://doi.org/10.3126/bdg.v20i0.20724

Cardenes, V., Neupane, N.R., Paudel, L.P., Crudde, V., and Crudde, J.P., 2016, Technological characterization of roofing slate from Nepal. Jour. Nep. Geol. Soc. v. 50, pp. 19-23. https://doi.org/10.3126/jngs.v50i1.22849

Chakrabarti, C.K. (1982). Zinc-lead mineralization in Ganesh Himal region of central Nepal.Jour. Nep. Geol. Soc., v. 2, pp. 47-51.

CPIT, 1973. Report on the investigation of petroleum geology in the kingdom of Nepal. The Chinese Petroleum Investigation Team (CPIT), Peking, $73 \mathrm{p}$.

DMG, 2004. Mineral Resources of Nepal. Dept. of Mines and Geology, Kathmandu, 154 p.

DMG., 2011. Mineral Resources of Nepal. Dept. of Mines and Geology, Kathmandu, 170 p.

Enfalt, H.C., Kaphle, K.P., and Joshi, P.R., 1995, Trace elements in muscovite as a guide to gem tourmaline bearing pegmatites in Nepal. Jour. Nep. Geol. Soc., v. 2, pp. 141-158.

ESCAP., 1993, Geology and mineral resources of Nepal. Atlas of mineral resources of the ESCAP region, v. 9, 107 p.

Ghimire, J.R. and Dhakal, P., 2006. Exploration for polished and dimension stones in some parts of Makwanpur and Lalitpur districts of central Nepal. Dept. of Mines and Geology, Annual Report, v. 4, pp. 34-41.

Ghimire, J.R., Kharka, R.K., and Chakrabarti, C.K. 1996, Zinc and lead mineralization in Ganesh Himal region, central Nepal. Jour. Nep. Geol. Soc., v. 14, pp. 65-77.

Ghimire, J.R. andNapit, D.K., 2005, Exploration of polished/dimension stone in parts of Makwanpur district, central Nepal. Dept. of Mines and Geology, Annual Report, no. 2, pp. 30-38.

Ghosh, A.K., Thorpe, R.I., and Chakrabarti, C.K., 2001, Age of metamorphosed base metal deposits of Ganesh Himal, central Nepal, compared with some similar deposits in the eastern Lesser Himalaya. Jour. Nep. Geol. Soc. v. 24 (Sp. Issue), P. 45.

Jnawali, B.M., 2009, Tectonic setting of the Nepal Himalaya and its potential for hydrocarbon exploration. Jour. Nep. Geol. Soc., v. 39, pp. 77-84.

Joshi, P.R., Jnawali, B.M., and Shakya, R.R., 1994, Narapani Limestone deposit, Arghakhanchhi district. Dept. of Mines and Geology, Precis No. 1, Lainchaur, Kathmandu, 4 p.

Kaphle, K.P., 1979, Geological report on Chaukune cement grade limestone, Chaukune area, Surkhet, DMG 
Unpublished report, 24p.

Kaphle, K.P.,1997, Phosphorite exploration in Nepal. Bulletin of Nepal Geo. Soc., v. 14, pp 67-68.

Kaphle, K.P., 2005, Dolomite resources in Nepal and their uses. Bulletin of Nepal Geo. Soc. v.21, pp. 49-50.

Kaphle, K.P. and Khan, H.R. 2006. Exploration and assessment of Those iron deposit in Ramechhap district, central Nepal. Dept. of Mines and Geology, Annual Report, v. 3, pp. 9-24.

Kaphle, K.P., 2011, Himalayan gemstones and their prospects in Nepal. Bull. Nep. Geol. Soc. v. 28, pp. 43-50.

Kaphle, K.P., 2012, Exploration results of Thosheiron ore deposit, Ramechhap, Nepal. Jour. Nep. Geol. Soc. v. 43, Special Issue, pp. 153-166.

Kaphle K.P., 2018, Mineral Resources of Nepal and their present status. Website of Nepal Geo.Soc.,www.ngs.org.np

Karki, A. andPaudel, L.P., 2016. Geological setting and quality of Bandipur Slate, Tanahun district, western Nepal Himalaya. Jour. Nep. Geol. Soc., v. 52 (Sp. Issue), 39p.

Karmacharya, S.L., 2003. Preliminary follow-up investigation of cement grade limestone in Udayapur district for the fiscal year 2057/2058. Dept. of Mines and Geology, Annual Report, no. 1, pp. 45-47.

Karmacharya, S.L., 2005. Preliminary investigation of limestone in between Ahalepakha (Sindhuli) and BaruwaKhola (Udaypur) Area, eastern Nepal. Dept. of Mines and Geology, Annual Report, no. 2, pp. 24-29.

Khandka, D.R., 2007, Preliminary exploration of limestone and dolomite around Kerabari and Sisne Khola area, Palpa district, western Nepal, Dept. of Mines and Geology, Annual Report, v. 4, pp. 25-29.

Malla, P.B., 1991. Field report on the Phulchauki Iron and leadzinc deposits, Kathmandu.Bull. of Dept. of Mines and Geology, v. 1, pp. 11-28.

Pant, T.R., 2003, Report on follow up investigation of limestone prospects in Baitadi district, Dept. of Mines and Geology, Annual Report, no. 1, pp. 50-52

Pant, T.R., 2005, Diyari Gad and Chauraha Limestone deposits of Baitadi district, far western Nepal. Dept. of Mines and Geology, Precis, no. 7, pp. 1-6.

Pant, T.R., 2006, Investigation of Kajeri Limestone Deposit of Sallyan district, mid-western Nepal. Annual Report, Dept. of Mines and Geology, No. 3, pp. 32-36.

Pant, T.R., 2007. Preliminary exploration of limestone and dolomite around Kerawari and Sisne Khola area, Palpa district, western Nepal. Dept. of Mines and Geology,
Annual Report, no. 4, pp. 25-39.

Paudyal, K.R., 2015, Occurrences of mineral resources in Bandipur-Gondrang area of Tanahun district, central Nepal, Lesser Himalaya, Journal of Science and Engineering, Khowpa Engineering College, Bhaktapur, v. 2, pp. 24-35. https://doi.org/10.3126/jsce.v2i0.22484

Pradhan, B.M. and Singh, Y.L., 1991, Preliminary report on the investigation of the reported nickel and copper ores and their mineral occurrences in east No. 1, Nepal. Bull. Dept. of Mines and Geology, v. 1, pp. 29-35.

Rimal, L.N and Ghimire, J.R. 2010, An account on the prospects of cement grade limestone in the Markhu Formation, Lesser Himalaya, Central Nepal. Jour. Nep. Geol. Soc., V. 41 (Sp. Issue). 66p.

Sah, R.B., 2015, Stratigraphy of Nepal. SAN (Sp. Issue), v. 10, $194 \mathrm{p}$.

Sah, R.B., Joshi, G.R., Pandey, P.R., Zakai, A.R, Devkota, B., Yadav, K., Maharjan, D.K., and Neupane, N.R., 2003, Geology and Mining of cement grade limestone of Sindhali, Udayapur, Eastern Nepal. Jour. of SAN, v. 4, pp. 26-31.

Shrestha, U.B., 2003, Exploration of polished stone in parts of Makwanpur District. Dept. of Mines and Geology, Annual Report, no. 1, pp. 53-58.

Shrestha, U.B. and Napit, D.K., 2001, Dimension stones of Makwanpur district, central Nepal. Jour. Nep. Geol. Soc., v. 24 (Sp. Issue). P. 46.

Shrestha, S and Dangol, V., 2007, Geology and reserve estimation of natural gas deposit at Teku area, Kathmandu Valley Jour. of SAN, v. 6, pp. 33-38.

Suwal, R.N., 1991, Field report on Phulchauki Iron ore and lead-zinc deposits, Kathmandu. Bull. of Dept. of Mines and Geology, v.1, pp. 11-28.

Tuladhar, R.M., 1982, A note on the lignite occurrences in Lukundol, Kathmandu. Jour. Nep. Geol. Soc., v.2, pp. 47-51.

Tuladhar, R.M., 1991, Stratabound zinc and lead mineralization at Phakuwa, Sankhuwasabha district. Jour. Nepal. Geol. Soc. (Sp. Issue), v. 7, pp. 41-58.

Uhlic, F.C., Haserberger, K., and Kirchner, E.C., 1998, Red and violet gahnite (spinel) occurrences in Ganesh Himal (Central Nepal): their chemistry, inclusions and microthermometry. Jour. Nep. Geol. Soc., v. 17, pp. 29-35.

Walter, L. and Werner, G., 2003. Manual on the geologicaltechnical Assessment of mineral construction materialsHannover, 498 p. 
